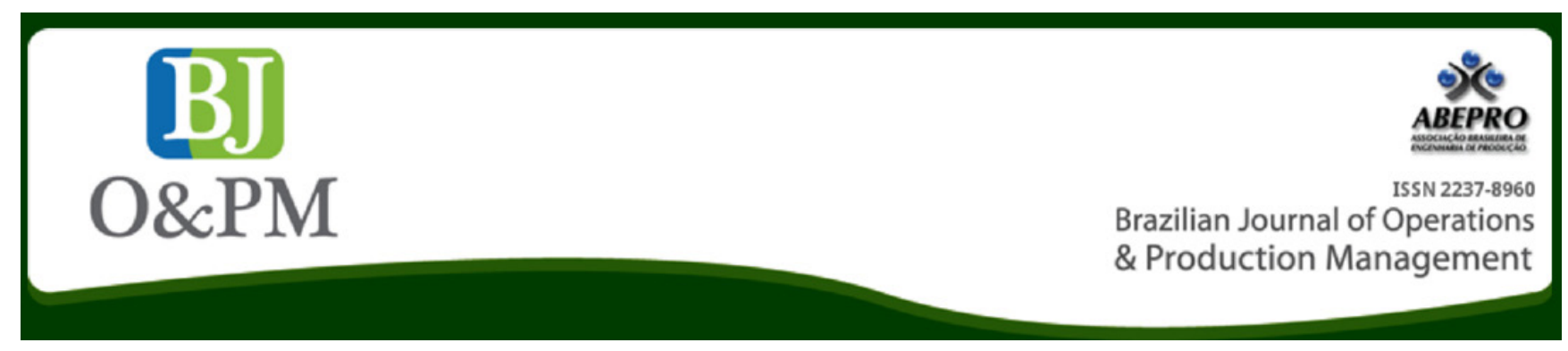

\title{
STUDY ON TECHNIQUES AND TOOLS USED IN LEAN HEALTHCARE IMPLEMENTATION: A LITERATURE REVIEW
}

\author{
Andreia Macedo Gomes ; Pedro Senna ${ }^{a}$; Aluisio Monteiro ; Denis Pinhab

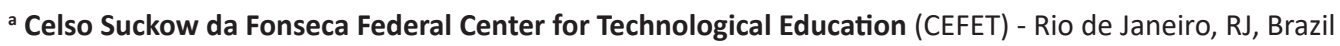 \\ ${ }^{b}$ West Virginia University (WVU) - Morgantown, WV, EUA
}

\begin{abstract}
Lately, Lean philosophy is increasingly gaining importance due to a competitive environment, which creates the need of reducing costs. Lean practices and tools have been applied to manufacturing, services, supply chains, startups and the next frontier is Healthcare. Most of lean techniques can be easily brought to Healthcare organizations. Therefore, this paper aims to summarize Lean practices and tools which are already being applied to Healthcare organizations. As its main results, we can highlight main authors, papers and number of publications per year and so, this paper can be used as a guideline for Lean implementations in Healthcare organizations.
\end{abstract}

Keywords: Lean tools; Lean Healthcare; Literature review. 


\section{INTRODUCTION}

Facing intense competition and the inability to meet an increasingly growing demand, makes healthcare organizations to seek structural and organizational changes in order to achieve performance improvement. Implementation of Lean methodology in healthcare establishments is known as Lean healthcare, and it has been a growing alternative in terms of quality pursuit, being based on patient's needs and saving resources that can bring positive results concerning quality of care and costs. Cheng et al., (2015) corroborates with that vision affirming that the application of Lean in healthcare over the past decade has been associated with increased quality, safety and efficiency by improving clinical processes.

Looking to adopt Lean philosophy in health services, many organizations have adopted different approaches and improvement strategies. There are a large variety of tools and techniques which can be used by health organizations in this regard. For example, Aguila-Escobar et GarridoVeja (2012) discussed the applicability of Lean principles in the supply chain management of a hospital through the implementation of the Kanban system. McClean et al., (2007) showed the use of a Markov Model to identify more efficient patients' routes in a hospital, which could also be associated with healthcare process improvement technologies such as Lean Thinking and Six Sigma methodology. Studies of DiGioia et al., (2015) show integration of two approaches by adding the Patient and Family Centered Care Methodology and Practice (PFCCM / P) to Lean methodology. According to the authors, by integrating two approaches we can keep the patient (and family) as the main focus for improvement activities and accelerate the pace of improvements.

Several other approaches and techniques related to Lean have been described in the literature, for example, Cheng et al., (2015) showed papers where Lean is applied through various approaches, and show results such as improvements in quality of health services and cost reduction. In this sense, incorporation of Lean healthcare management processes can bring benefits to healthcare organizations based on many success stories. However, McIntoshi et al., (2014) said there is still no evidence in literature that supports the acceptance of Lean success in health services concerning strategic objectives. In this context, knowing the tools and techniques that makes application of Lean Healthcare possible can contribute to a better understanding of Lean approach in health services.

In this sense, this paper has the objective of building a systematic literature review from a survey conducted from SCOPUS database in order to know which are the main techniques and most used tools for the implementation of Lean philosophy in healthcare. We also discuss concepts such as Agile et Leagile. Section 2 presents the research methodology used in the search for references and data analysis. In section 3 the concepts of Lean, Lean healthcare, Agile et Leagile are presented based on references. Section 4 presents a detailed analysis of what have been published on Lean Healthcare, in addition, this section also presents a scheme detailing the main techniques for applying the Lean concept in health care based on articles found. Section 5 presents discussion of obtained results and Section 6 presents conclusions of the paper

\section{RESEARCH METHODOLOGY}

This study is characterized as a systematic literature review on Lean Healthcare. The systematic review requires a rigorous methodological framework. Therefore, the content analysis is an effective tool for analyzing a sample of research documents in a systematic way (SEURING et GOLD, 2012). The model proposed by Seuring et Gold (2012) to conduct a systematic review by content analysis consists of four steps:

1- Collecting material,

2- Descritive analysis,

3- Category selection,

4- Material assessment.

The first step was taken from the search publications performed by finding literature production in SCOPUS database using the string "Lean Healthcare". The search took place in August 2015, have resulted in a total of 612 publications. Then an initial screening of publications found by checking titles and abstracts was performed, aiming to discard those that did not fit within the scope of this research, resulting in 277 articles ranging from the years 2002 to 2015. To organize publications we used Mendeley Desktop reference management tool.

The second step is reading of the texts in which could be identified the central idea of the articles and the main results found by the authors. From the information collected, analyses were performed sorting the papers by year of publication, country, major authors, journals, among others.

Third step was a paper categorization based on criteria shown in Figure 1. A conceptual model was created, where the criteria are divided into three main blocks, and then, divided again into subcategories:

1- General paper information concerns year of publication, journal title, journal country and author

2- Research method: Papers were sorted as conceptual and practical. Conceptual papers are those which assess what is being published about Lean Healthcare. Most of them are literature reviews. Practical papers are considered those which bring applications and case studies. 

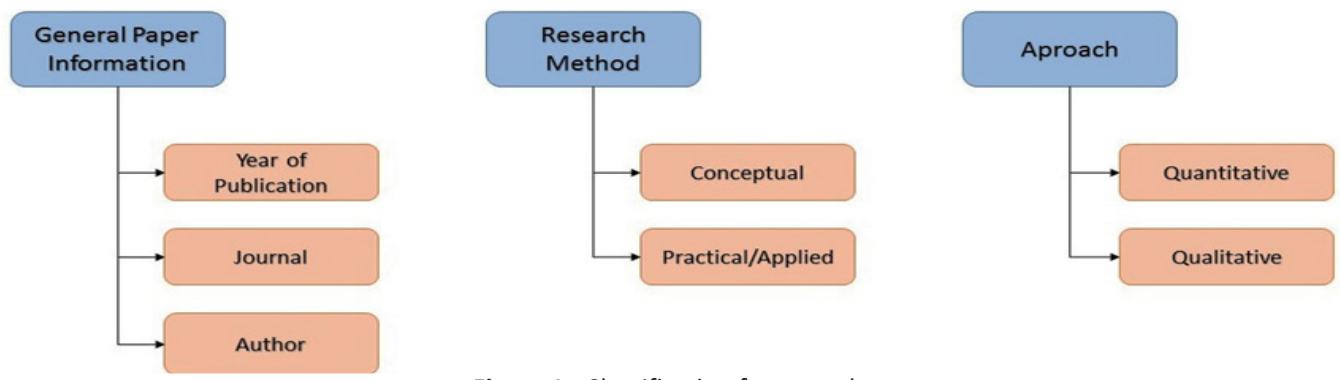

Figure 1 - Classification framework.

Source: The authors own.

3- Approach: This section sorts the papers as quantitative and qualitative. Quantitative papers were considered those, which bring numerical examples. Qualitative papers were considered those that bring framework and methodological applications.

\section{LITERATURE REVIEW}

This section aims to discuss how Lean philosophy is being applied to Healthcare organizations. We also bring discuss concepts such as Agile et Leagile (AGARWAL et al., 2006).

\subsection{Lean Concepts}

In recent years, there is a growing interest regarding studies and implementation of "Lean Manufacturing" concept, as well as broader concepts such as "Lean Company ". The main focus of lean approach is elimination of excess. The consolidation of Toyota Production System can be considered the key to popularization of large-scale lean production systems, which has strong emphasis on eliminating waste (AGARWAL et al.,2006). The authors also claim that the Lean policy works well in environments where demand is relatively stable, predictable, and there is little variety. Lean policy, can even function as an agility element occasionally, but will not always be enough to meet customers' demands.

Many industries are adopting new business tactics in order to survive in the new market logic, and in this sense, waste disposal becomes a critical survival issue (ARADHYE et KALLURKAR, 2014).

Production systems that use large stocks, large lots and uninterrupted production, increasingly give way to more flexibility, in order to get more competitive systems, thus making Lean Production and Lean Manufacturing systems as some of the most popular around the world (ARADHYE et KALLURKAR, 2014; KOJIMA, 2008).

In this context, Muda is the term for an activity that is considered wasteful and does not add value or is unproductive. Lean suggests that in order to create capacity in the workplace we are best off identifying areas of waste and working towards eliminating them from our processes.
Generally there are seven wastes primary root causes for inefficiency within the work space (waiting, stock, overprocessing, quality errors, motion, transportation, and processing)

Table 1 brings recent studies and applications of Lean concepts:

Table 1 - Papers concerning Lean initiatives.

\begin{tabular}{|c|c|}
\hline Authors & Methods and highlights \\
\hline \multirow[t]{2}{*}{ Lin, 2011} & $\begin{array}{l}\text { Application of VMI for obtaining Lean Supply. The design } \\
\text { of a lean inventory management system needs a system } \\
\text { designed to incorporate all relevant constraints on the } \\
\text { system. }\end{array}$ \\
\hline & $\begin{array}{l}\text { The author argues that for a complex chain, inventory } \\
\text { management system should be Lean. }\end{array}$ \\
\hline $\begin{array}{l}\text { Behrouzi } \\
\text { et al., } \\
2011\end{array}$ & $\begin{array}{l}\text { The paper collects data from } 133 \text { Iranian automotive } \\
\text { companies. It Creates a set of performance measures } \\
\text { based on four components: Elimination of waste, } \\
\text { continuous improvement, flexibility and JIT (Just-in-Time). }\end{array}$ \\
\hline $\begin{array}{l}\text { Martínez- } \\
\text { Jurado et } \\
\text { Moyano- } \\
\text { Fuentes, } \\
2013\end{array}$ & $\begin{array}{l}\text { This paper brings Literature assessment of connections } \\
\text { between concepts such as Lean Management, Supply } \\
\text { Chain Management and Sustainability. There are significant } \\
\text { gaps in the literature as regards sustainability applied to } \\
\text { lean supply chain management. }\end{array}$ \\
\hline $\begin{array}{l}\text { Chen et } \\
\text { al., } 2013\end{array}$ & $\begin{array}{l}\text { This study applies Lean Production and RFID (Radio } \\
\text { Frequency Identification) to improve effectiveness in a } \\
\text { Supply Chain. The authors also show savings achieved for } \\
\text { the chain as a whole with application of Lean techniques. }\end{array}$ \\
\hline $\begin{array}{l}\text { Tritos et } \\
\text { al., } 2013\end{array}$ & $\begin{array}{l}\text { Authors show a holistic approach to prioritizing Lean } \\
\text { SCM (Supply Chain Management) initiatives applied to } \\
\text { Healthcare. A Fuzzy AHP method was used to prioritize } \\
\text { the categories: Continuous Improvement Process, JIT flow } \\
\text { management, enterprise integration and elimination of } \\
\text { waste. The results indicate that continuous improvement } \\
\text { is a dominant Lean SCM initiative due to financial and } \\
\text { operational performance focus. }\end{array}$ \\
\hline $\begin{array}{l}\text { Manzouri } \\
\text { et } \\
\text { al.,2014 }\end{array}$ & $\begin{array}{l}\text { Study aimed to identify the best Lean tools from } 300 \\
\text { questionnaires distributed in food firms in Malaysia. } \\
\text { The results showed that collaborative demand planning, } \\
\text { continuous improvement and good inventory management } \\
\text { practices are the most important tools for Lean Supply } \\
\text { Chain. }\end{array}$ \\
\hline $\begin{array}{l}\text { Safaei, } \\
2014\end{array}$ & $\begin{array}{l}\text { The study presents a multi-objective programming model. } \\
\text { The example brought by the authors show costs and waste } \\
\text { minimization, leading to conclude that operations research } \\
\text { models are good approaches. }\end{array}$ \\
\hline
\end{tabular}

Source: The authors own.

Table 1 analysis shows that authors reinforce basic principles of Lean, such as elimination of waste in all its forms, with greater emphasis on inventory, besides strong inclination for the application of VSM. We can also 
Brazilian Journal of Operations \& Production Management

Volume 13, Número 4, 2016, pp. 406-420 DOI: 10.14488/BJOPM.2016.v13.n4.a1

highlight the fact that continuous process improvement is a prerequisite for obtaining a lean production system. The authors also emphasize the importance of using quantitative techniques, such as Operations Research to find optimum cost.

\subsection{Agile Concepts}

In light of this discussion, there is still the fact that there are risks inherent in building a lean system. These risks have already broken organizational boundaries and can pose risks to the entire supply chain. This fact drew attention of authors such as Tang et Muse (2011); Jutner et al., (2003); Thun et Hoenig (2011), among others. Thun et Hoenig (2011) work with the concept of Supply Chain Risk Management, which would be the risk management discussion that are not restricted to just one tier in the chain, but risks that can compromise business processes going through one or all of the companies in a Supply Chain.

The balance of these risks is not an easy task. For building a Lean Supply Chain, it is imperative to include business process coordination tools, as well as maturity and integration between all parties. There is also need for process mapping, reduction of intermediate stocks, among other challenges. However, if coordination is not possible in the whole Supply Chain, or if the environment is subject to a degree of uncertainty, the buffers are tend to increase along the chain, margins decrease and competitiveness weakens. Some researchers believe that speed is associated with efficiency and consider it fundamentally different from lean logic (GOLDSBY et al.,2006).

Classically, Lee (2002) states that companies should use Agile philosophy in a more uncertain environment and Lean philosophy in environments with more stability. This premise is questioned by Gligor et al., (2014) who claim that Agile philosophy works equally well in stable environments.

Agility is considered a key attribute for all organizations in a business environment subject to many uncertainties (BALAJI et al.,2014; SANGARI et al.,2015). Over time, the idea that companies must be agile is consolidating more and more (Gligor et HOMCOMB, 2012a ; Gligor et al.,2014.). Gligor et al., (2014) define mobility of a Supply Chain as the ability of a company to quickly adjust their tactics and operations to changes in the environment. The Agility is defined as the ability of a chain to use its resources to quickly respond to environmental changes (LI et al.,2008). Naylor et al., (1999) define agility as the ability to use market knowledge and a virtual corporation to exploit profitable opportunities in a volatile market environment.

Agile philosophy involves rapid setup and removal of wastes, however, such elimination is not considered a prerequisite (NAYLOR et al.,1999). For Balaji et al., (2014), mobility can be achieved by improving the relationship between buyers and suppliers in a supply chain.

\subsection{Leagile Concepts}

Up to this point, Lean et Agile paradigms were presented, however, Lean et Agility paradigms are no longer sufficient to generate competitiveness in business. Nowadays, it is necessary that the lean concept is applied in conjunction with agility concept and so, the term Leagility is coined and is discussed, for example in Naylor et al., (1999) and most recently in Huang et Li (2010). The term leagile comes from the hybrid combination of the lean and agile concepts, and the appropriate concept in the supply chain will depend upon the requirements of the customer.

Many researchers came up with the term "Decoupling Point" (See Cristopher, 2000; Cristopher et Towill, 2000; Mason-Jones et al.,2000). The idea was that a point of decoupling separates processes that would work on the Lean logic and processes that would work in Agile Logic (HUANG et LI, 2010; PRICE et KAY, 2000; VAN DER WORST et al.,2001). Table 2 summarizes papers that discuss agile concept.

Table 2 - Papers using "agile" concept

\begin{tabular}{|c|c|}
\hline Authors & Methods and Highlights \\
\hline $\begin{array}{l}\text { Wang et al., } \\
2011\end{array}$ & $\begin{array}{l}\text { The paper emphasizes the importance of flexibility } \\
\text { and applies Mobile Agent system, which facilitates the } \\
\text { exchange of information among other benefits. The } \\
\text { research also points out that the competitions are } \\
\text { among chains and no longer between companies and } \\
\text { highlights how Mobile Agent type systems facilitate } \\
\text { the agile production. }\end{array}$ \\
\hline $\begin{array}{l}\text { Ghahremanloo } \\
\text { et Tarokh, } \\
2011\end{array}$ & $\begin{array}{l}\text { The authors Propose an ACSM (Agile Supply Chain } \\
\text { Management) based on multi-agent systems. The } \\
\text { model is validated using multi-objective fuzzy linear } \\
\text { programming and is able to select the best supplier in } \\
\text { accordance with a combination of agility criteria in a } \\
\text { optimized mathematical model. }\end{array}$ \\
\hline $\begin{array}{l}\text { Chen et al., } \\
2011\end{array}$ & $\begin{array}{l}\text { This study analyzes the behavior of agile supply chains } \\
\text { using dynamic systems. For agile supply chain, the } \\
\text { delivery rate can be adjusted not only by changing } \\
\text { the order cycle time but also through targeted stock } \\
\text { change. }\end{array}$ \\
\hline $\begin{array}{l}\text { Benzheng, } \\
2011\end{array}$ & $\begin{array}{l}\text { The author develops the scheme of incentive from } \\
\text { the economic theory of the principal agent. For } \\
\text { example, suppliers can take improper actions that are } \\
\text { good for them, but bad for the chain. }\end{array}$ \\
\hline $\begin{array}{l}\text { Lei et wang, } \\
2012\end{array}$ & $\begin{array}{l}\text { The authors emphasize the importance of an agile } \\
\text { inventory management in a supply chain. Agile } \\
\text { inventory management in a supply chain can improve } \\
\text { the management of a company using parameters } \\
\text { such as fast and appropriate decision-making } \\
\text { process, lower production cycles, efficiency gains in } \\
\text { production, among others. }\end{array}$ \\
\hline $\begin{array}{l}\text { Ameri et Pati, } \\
2012\end{array}$ & $\begin{array}{l}\text { This study explains the multi-agent system called } \\
\text { Digital Manufacturing Market (DMM), which is a } \\
\text { multi-agent system that connects the chain links and } \\
\text { allows reconfiguration of the processes. }\end{array}$ \\
\hline $\begin{array}{l}\text { Samantra et } \\
\text { al., } 2013\end{array}$ & $\begin{array}{l}\text { The paper uses use fuzzy logic to evaluate agility in a } \\
\text { supply chain. The study was applied to an automotive } \\
\text { chain in India. The authors bring a summary of the } \\
\text { main techniques for measuring speed on a CS. The } \\
\text { intrinsic characteristics of fuzzy logic make it a good } \\
\text { technique to represent imprecise human judgments. } \\
\text { The model provides a quantitative approach to } \\
\text { estimate the degree of agility. }\end{array}$ \\
\hline
\end{tabular}




\begin{tabular}{|c|c|}
\hline $\begin{array}{l}\text { Ling et Feng, } \\
2013\end{array}$ & $\begin{array}{l}\text { Selection of partners consists of one key problem in } \\
\text { building an agile CS. The authors use optimization } \\
\text { by ant colony. The paper presents the mathematical } \\
\text { description of the model. }\end{array}$ \\
\hline $\begin{array}{l}\text { Balaji et al., } \\
2014\end{array}$ & $\begin{array}{l}\text { They use a methodology called Agile Supply Chain } \\
\text { Transformation Matrix (ASTM). The ASCTM tool is } \\
\text { built on QFD to identify the interaction between } \\
\text { business practices and AHP as method to support } \\
\text { multi-criteria decision. The authors present a } \\
\text { successful case in a medium-sized company. The } \\
\text { authors conclude that the ASCTM will provide basis } \\
\text { for evaluating processes and help companies to } \\
\text { survive in unstable environments }\end{array}$ \\
\hline $\begin{array}{l}\text { Yusuf et al., } \\
2014\end{array}$ & $\begin{array}{l}\text { The paper evaluates the link between dimensions } \\
\text { of an Agile Supply Chain, competitive goals and } \\
\text { performance in an oil and gas British company. } 880 \\
\text { questionnaires were applied to identify agility criteria. } \\
\text { The article identifies the most important dimensions } \\
\text { and attributes of an agile SC and emphasizes } \\
\text { the importance of chain competition instead of } \\
\text { competition between firms. }\end{array}$ \\
\hline $\begin{array}{l}\text { Gligor et al., } \\
2015\end{array}$ & $\begin{array}{l}\text { The article brings a question about the possibility } \\
\text { of the agile philosophy work well in more stable } \\
\text { environment. The technique used is the structural } \\
\text { equation modeling. At the end, the study concludes } \\
\text { that agility has a positive effect on customer service } \\
\text { but conclude that there is still a agile firm to be } \\
\text { efficient in costs }\end{array}$ \\
\hline $\begin{array}{l}\text { Sangari et al., } \\
2015\end{array}$ & $\begin{array}{l}\text { The paper combines fuzzy logic with ANP (Analytic } \\
\text { Network Process) to create a framework in a chain } \\
\text { that wants to increase agility. For the automotive } \\
\text { industry presented, the method ranks the most } \\
\text { important factors for agility }\end{array}$ \\
\hline
\end{tabular}

Source: The authors own.

\subsection{Lean, Agile and Leagile concepts applied to Healthcare}

Due to a cost reduction emphasis, Lean methodologies have become a consolidated set of practices and tools, which aim to improve processes while reducing costs. Recently, Lean practices are being applied to Healthcare organizations. Such practices led many researchers to coin the term "Lean Healthcare". Basically, a healthcare unit is a facility which provides direct or indirect services to promote or keep individuals' health condition (INTERNATIONAL PROFILES OF HEALTHCARE SYSTEMS, 2012).

Lean manufacturing is a management approach aiming to improve the performance of an organization by reducing waste, delays, etc. while involving staff in decision-making (BARIL et al.,2015). Lean basically consists in reducing waste, in this context, long waiting times reduce healthcare quality and so, Lean offers a broad set of tools which can help healthcare organizations to relief the pressure of an environment with limited resources and a growing patient population (YU et al.,2015). Considering the increasing needs for services in healthcare, hospital services must review their practices to improve them and increase their performance. Healthcare facilities look toward continuous improvement approaches such as Lean manufacturing to improve service delivery (HOUCHENS et KIM, 2014).
Lean implementation in healthcare requires adaptation and development to fit the specific context and allow healthcare staff to take ownership of the approach (Poksinska, 2010). Lean Healthcare is one of the last management imports to healthcare sector (Mazzocato et al.,2010), and is also a methodology that enables hospitals to improve patient care quality, support employees and doctors, eliminate barriers and focus on providing care (Graban, 2012)

Due to criteria such as publication year (the more recent, the better) and Lean tools use, we constructed Table 3, which shows the most relevant papers and its highlights.

Table 3 - Lean Healthcare papers

\begin{tabular}{|c|c|}
\hline Authors & Methods and Highlights \\
\hline Yu et al., 2015 & $\begin{array}{l}\text { The authors use VSM to redesign inefficient processes } \\
\text { in an oncologic clinic. }\end{array}$ \\
\hline $\begin{array}{l}\text { Lasorsa et al., } \\
2015\end{array}$ & $\begin{array}{l}\text { The authors highlight the lack of a healthcare } \\
\text { standardized framework for implementing Lean } \\
\text { Healthcare tools. The paper proposes a method } \\
\text { for standardizing lean management approach in } \\
\text { Healthcare. }\end{array}$ \\
\hline $\begin{array}{l}\text { Baril et al., } \\
2015\end{array}$ & $\begin{array}{l}\text { The paper uses a combination of discrete-event } \\
\text { simulation to test scenarios defined by kaizen event } \\
\text { team members. }\end{array}$ \\
\hline $\begin{array}{l}\text { Bhat et al., } \\
2015\end{array}$ & $\begin{array}{l}\text { The authors use Lean Six Sigma approach to improve a } \\
\text { medical records department }\end{array}$ \\
\hline $\begin{array}{l}\text { Bastian et al., } \\
2015\end{array}$ & $\begin{array}{l}\text { The article presents a framework for assess, measure } \\
\text { and improve clinical workflow processes. }\end{array}$ \\
\hline $\begin{array}{l}\text { Curatolo et } \\
\text { al., } 2014\end{array}$ & $\begin{array}{l}\text { This conceptual paper shows analysis concerning if } \\
\text { Lean approaches provide sufficient methodological } \\
\text { support for reproduce obtained results. For Lean to be } \\
\text { adopted and implemented by hospital practitioners a } \\
\text { structured robust method should be provided. }\end{array}$ \\
\hline $\begin{array}{l}\text { Dias et al., } \\
2013\end{array}$ & $\begin{array}{l}\text { The authors propose a method to find non-value } \\
\text { added activities and so redesign the process } \\
\text { eliminating such activities. }\end{array}$ \\
\hline $\begin{array}{l}\text { Chiocca et al., } \\
2012\end{array}$ & $\begin{array}{l}\text { The authors used PowerSim software to test Lean tools } \\
\text { in a process of vaccines delivery }\end{array}$ \\
\hline $\begin{array}{l}\text { Nicholas, } \\
2012\end{array}$ & $\begin{array}{l}\text { The paper presents patients fit and lower cost hospital } \\
\text { facilities redesign. }\end{array}$ \\
\hline $\begin{array}{l}\text { Kuo et al., } \\
2011\end{array}$ & $\begin{array}{l}\text { The article aims to propose a method called } \\
\text { Healthcare Lean Six Sigma System which integrates } \\
\text { Lean and Six Sigma to improve postanesthesia care } \\
\text { unit processes. }\end{array}$ \\
\hline $\begin{array}{l}\text { Villarreal et } \\
\text { Yilmaz, } 2010\end{array}$ & $\begin{array}{l}\text { Lean principles were used to develop a patient-centric } \\
\text { process focusing only on essential activities while } \\
\text { eliminating the non-value added ones. }\end{array}$ \\
\hline
\end{tabular}

Source: The authors own.

We also highlight that the term "Agility" (in the context shown) is always associated with "Lean" and decoupling points which separates which parts of the process are Lean and which parts are Agile. There were no papers, which brought case studies of a purely agile Healthcare process. Table 4 shows papers found which show how to implement Leagile in Healthcare organizations. 
Table 4 - Leagile Healthcare papers

\begin{tabular}{|l|l|}
\hline \multicolumn{1}{|c|}{ Authors } & \multicolumn{1}{c|}{ Methods and Highlights } \\
\hline $\begin{array}{l}\text { Rahimnia et } \\
\text { Moghadasian, } \\
2010\end{array}$ & $\begin{array}{l}\text { The paper shows an application of leagility concepts } \\
\text { in an Iranian hospital. It groups the healthcare } \\
\text { services into three pipelines, and them, identifies the } \\
\text { decoupling points for the supply chain. }\end{array}$ \\
\hline $\begin{array}{l}\text { Guven-Uslu et } \\
\text { al., 2013 }\end{array}$ & $\begin{array}{l}\text { The authors applied a decoupling point in a crucial } \\
\text { process so Lean and agile philosophies could coexist. }\end{array}$ \\
\hline $\begin{array}{l}\text { Guimarães et } \\
\text { Carvalho, 2012 }\end{array}$ & $\begin{array}{l}\text { The papers brings concepts such as leagility and } \\
\text { modularity applied to a healthcare organization. }\end{array}$ \\
\hline
\end{tabular}

Source: The authors own.

\section{RESULTS}

Following the research method described in section 2 , we found 612 potentially relevant articles concerning the topic Lean Healthcare. After initial filtering, we excluded articles that did not fit in the scope of the research, resulting in 213 articles. After reading the texts, we excluded 38 articles that did not have enough information to identify the lean technique or the tool applied, totaling 175 articles ranging from the years 2002 and 2015.

The sample included publications from 2002 to 2015 . An upward trend has been identified in the number of publications during the period, although we observed few publications in the early years and a peak occurred in 2014. Publications distribution can be seen in Figure 2.

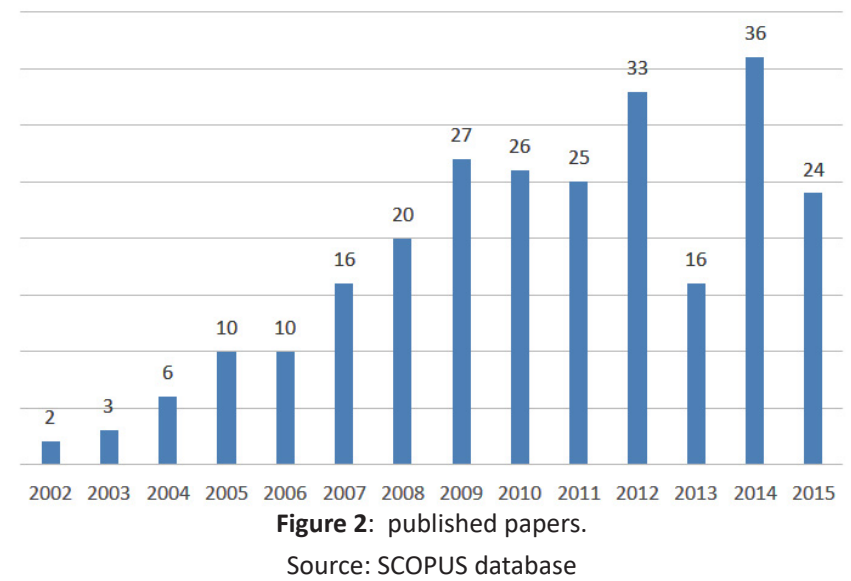

International Journal of Healthcare Quality assurance

Journal of Health Organization and Management

Leadership in Healthcare Services

Journal for Healthcare Quality

International Journal of Lean Six Sigma and Competitive Advantage
We also have identified the most relevant journals as shown in Figure 3. The journals in which were found more publications on the subject Lean Heathcare were "Lean International Journal of Six Sigma and Competitive Advantage" and the "Journal for Healthcare Quality", both with 8 publications found.

Table 5 classifies the authors with at least three articles published. Two authors had the highest number of publications and only one author presented three publications on lean healthcare.

Table 5: Authors with at least 3 papers published.

\begin{tabular}{|c|c|c|c|}
\hline Author & Papers & Affiliation & Country \\
\hline $\begin{array}{c}\text { Thanos } \\
\text { Papadopoulos }\end{array}$ & 4 & $\begin{array}{c}\text { University of } \\
\text { Southampton }\end{array}$ & UK \\
\hline Matt Morissette & 4 & $\begin{array}{c}\text { More Effective } \\
\text { Consulting }\end{array}$ & USA \\
\hline Nicolo Curatolo & 3 & $\begin{array}{c}\text { Arts et Metiers } \\
\text { Paris Tech }\end{array}$ & France \\
\hline
\end{tabular}

Source: SCOPUS database

The literature survey also show 56 different techniques or tools used in the implementation of Lean Healthcare. As can be seen in Figure 4, there is a variety of Lean tools and techniques. The techniques most used by the authors were Six Sigma, Value Stream Mapping (VSM), Kaizen, 5S, process mapping/ improvement, simulation and PDCA / PDSA, being the Six Sigma technique the most frequently cited. About 27 Lean tools were cited only one time.

Figure 5 shows distribution of articles for paper type. As can be seen, the results show that there is a predominance of publications classified as practical / applied. Most publications in this category have one or more case studies or experience report to illustrate the application of Lean Healthcare.

The tools and techniques identified in this review were categorized as quantitative and qualitative. Considering the 54 techniques identified, 13 were classified as quantitative and 41 as qualitative. Figure 6 shows the distribution of quantitative tools, being six sigma the most used.

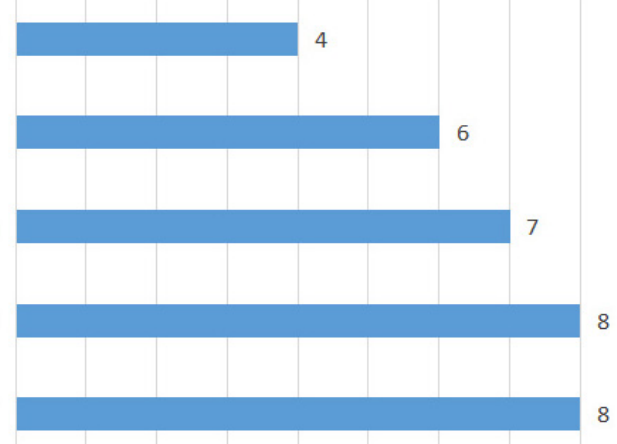

Figure 3: More relevant journals.

Source: SCOPUS database 


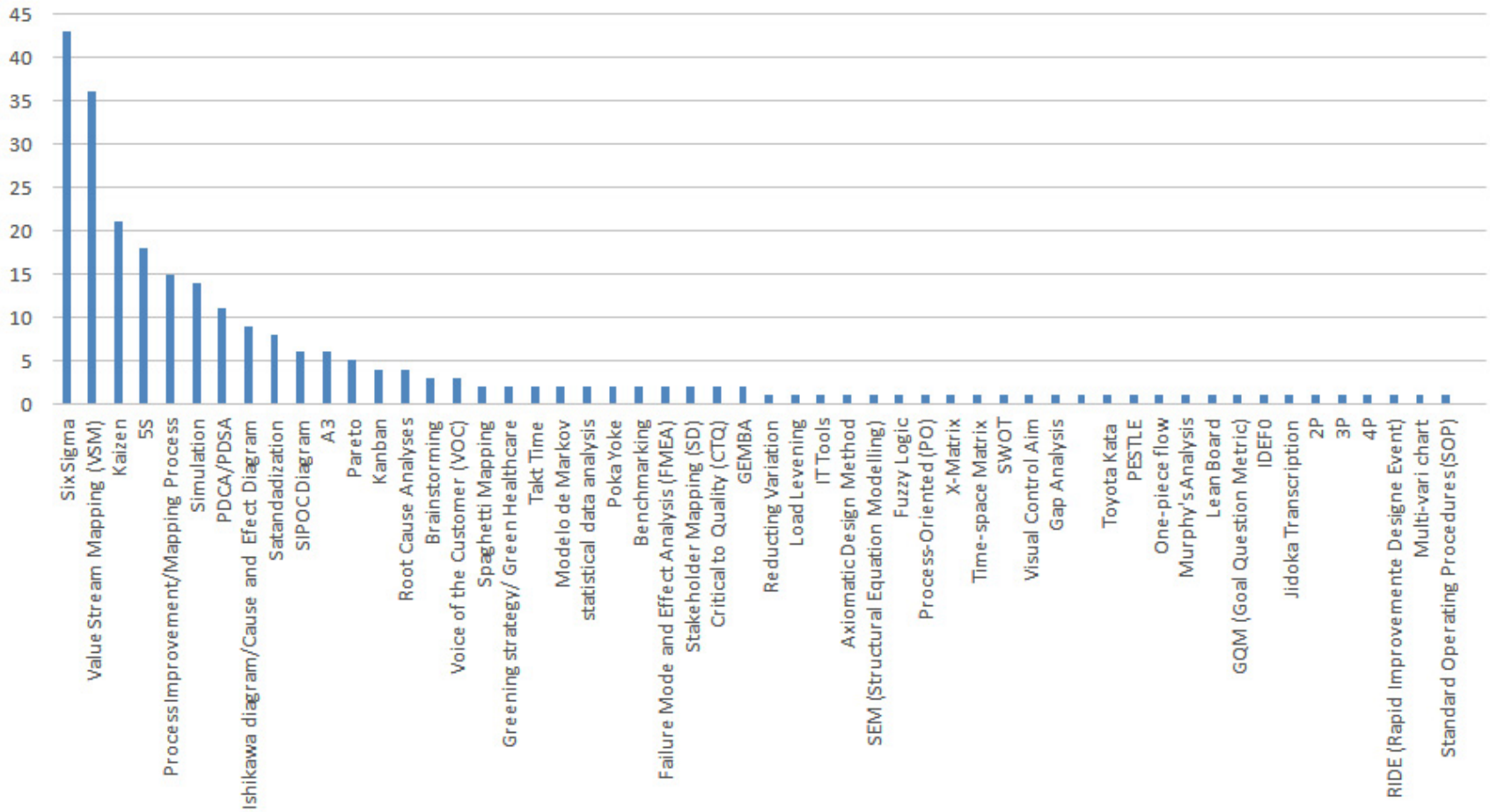

Figure 4: Techniques found in the papers.

Source: The authors own.

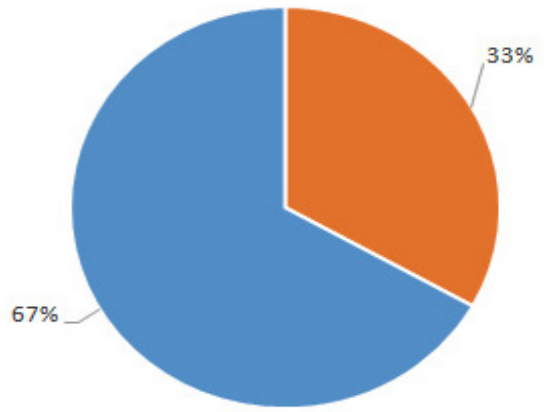

- Conceptual = Practical/Applied

Figure 5: Paper type. Source: The authors own.

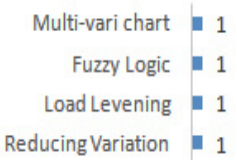

Figure 6: Distribution of quantitative techniques and tools. Source: The authors own.

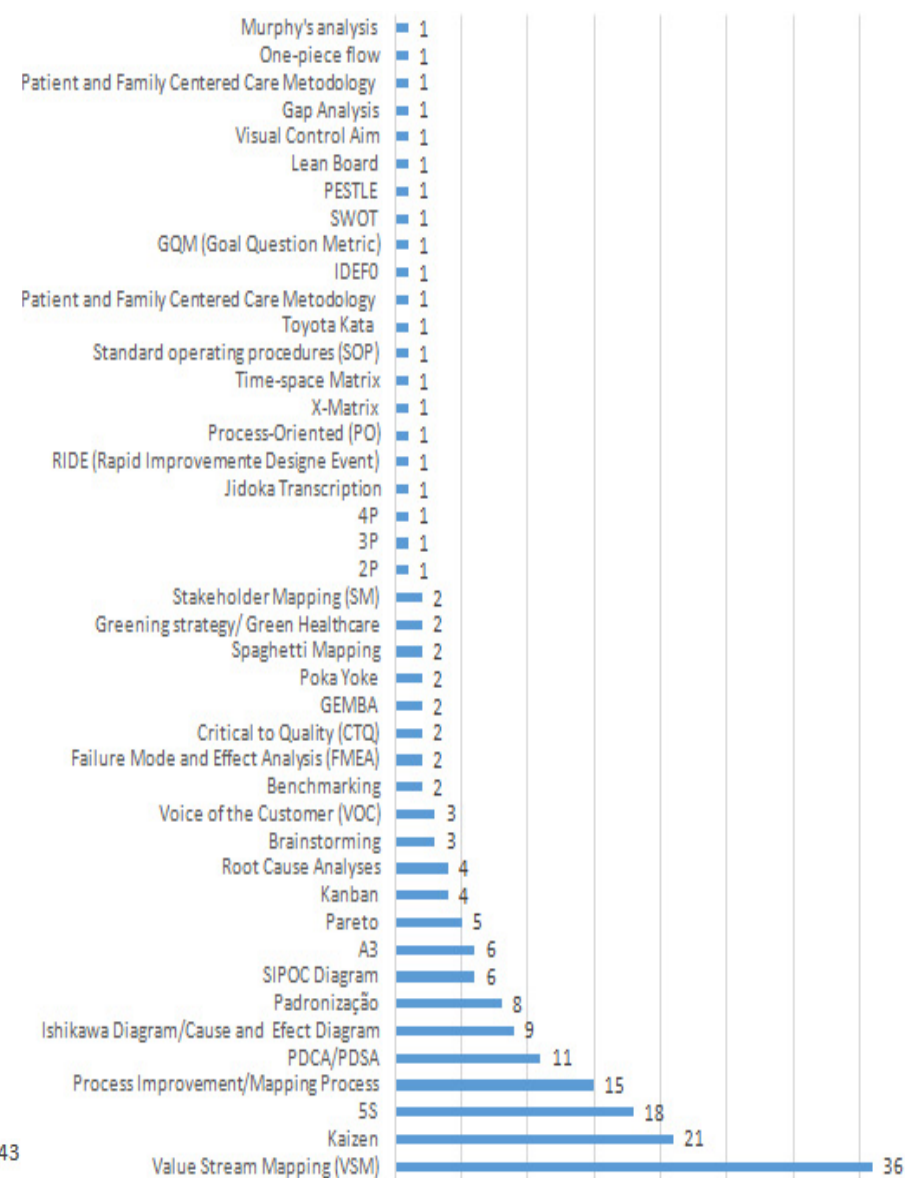

Figure 7: Distribution of qualitative tools and techniques. Source: The authors own. 


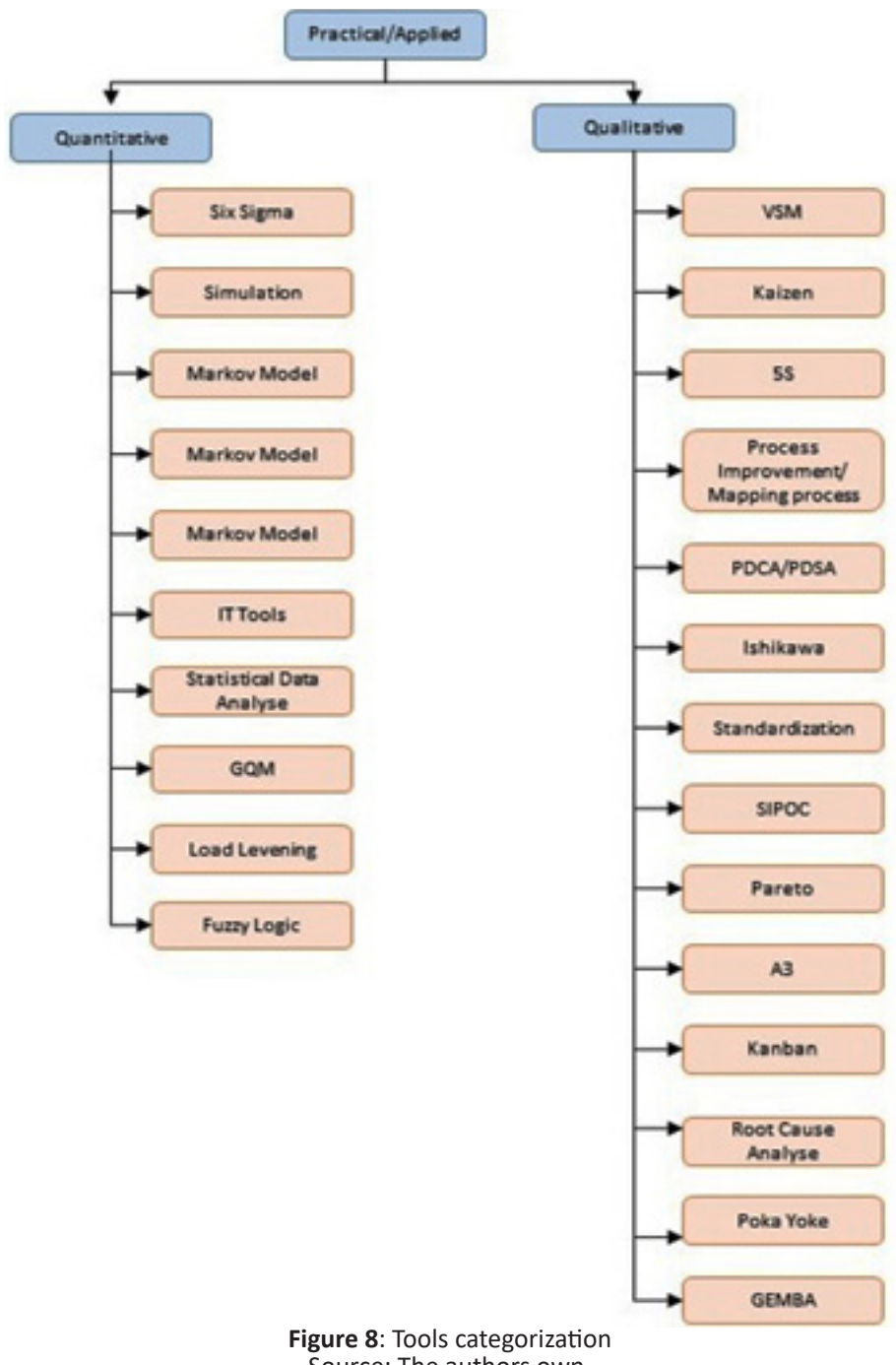

Figure 7 shows distribution of qualitative tools. The most quoted technique was the Value Stream Mapping (VSM) with 36 occurrences. Note that even being six sigma a qualitative/quantitative approach, we considered it quantitative because, usually, it is a mostly quantitative methodology.

Figure 8 shows a model with a summary of the main techniques and tools found in literature.

\section{DISCUSSION}

Based on the results shown in section 4, we discuss application of techniques used in Lean Healthcare (and also discuss agile and leagile concepts). This review included the main techniques and tools considering the evidence from the literature to determine how Lean can be applied in the health sector. D'Andreamatteo et al., (2015) cited in his review that it seems to exist in the literature a lack of uniformity in the concepts of Lean, and so, a common definition of what is and what is not Lean should be established so that future projects can be analyzed properly and strengthen research and practice.

The literature review showed that Six Sigma was the most mentioned technique by the authors. According to Yamamoto et al. (2010), Lean and Six Sigma work together to improve the overall performance. Several authors suggest bringing Lean and Six Sigma together resulting in Lean/Six Sigma approach. Such an approach was notably used by several authors such as: AGUEZZOUL et NYOUNGUE, 2012; AL owad. 2014;. BHAT et al., 2015; BAHENSKY et al., 2005; BONILLA et al., 2008;. CALDWELL, 2006; Carboneau et al., 2010; D'ANDREAMATTEO et al., 2015; GIJO et ANTONY, 2014; Haenke and Stichler, 2015; HEUVEL et al., 2006; Hoerl et Gardner, 2010; Huang et al., 2012; KOLLENGODE, 2008; Kuo et al., 2011; MANDAHAWI, 2011; Mason et al., 2014; Mozammel et al., 2011; NATALE et al., 2014; NICOLAY et al., 2012;. PHIPPS, 2012; Sanders et KARR, 2015; VEST et GAMM, 2009; WORKMAN-GERMANN et WOODWARD-HAGG, 2006; Yamamoto et al., 2010; YU et al, 2008; Zandi et BORCHERS, 2012. 
Also according to Yamamoto (2010), Lean/Six Sigma has recently been adapted for the healthcare industry with the aim of eliminating activities that do not add value, reduce waste, decrease the errors rate and variability in processes, in addition, aims to increase agility and process reliability. Lean/Six Sigma showed a very widespread method and good results which can be the cause of appearing so many times in literature. However, D'Andreamatteo (2015) states that the analysis of the benefits and criticism of a joint application with other techniques are still undervalued because in most cases the most common form of joint combinations with other methodologies is Lean/Six Sigma, in which is shown that the joint implementation could overcome the weak points of each system.

There is also some overlap between the tools and techniques such as VSM, Kanban, 5S, Ishikawa and SIPOC diagrams, which are usual techniques, but can be applied to as measuring tools for other methods. We can affirm that this is what happens with the tools used in Lean/Six Sigma, which is a fairly comprehensive methodology that makes use of several tools, and so, this research also noticed that most of the tools mentioned by the authors include the set of tools and methods used by the Lean Six Sigma. Some tools like PESTLE, Pareto, SWOT, brainstorming and benchmarking are not usually described as Lean tools, but were cited by authors as tools used in one or more stages of DMAIC framework (BHAT et al., 2015; GIJO et ANTONY, 2014; MANDAHAWI et al., 2011.). However, eventually, authors also used those tools as analysis' tools without necessarily being part of Six Sigma (Cheng et al., 2015; CREMA et al., 2015; CREMA et VERBANO, 2015; Robinson et al., 2012; Towill et Christopher, 2005).

Value Stream Mapping Tool (VSM) was a widely used tool by most of authors, being used alone or in conjunction with other tools. VSM represents key personnel, material, and information flows required to distinguish value-added steps and steps with no value (Jimmerson et al.,2005). Most articles which used VSM, have combined the tool with other techniques and tools, such as the work of Grove et al.,2010), Verbano Crema (2015) et Cheng et al., (2015). Even using only VSM can generate good results, allowing identification of waste and some operational bottlenecks that interfere with treatment of patients (Henrique et al.,2005). Among other benefits, we can highlight a faster and controlled patient flow, with less waste and shorter waiting time (Demirli et BHUIYAN, 2015). In addition, the literature review showed that the VSM is a widely used tool in the implementation of Lean/Six Sigma (VILLA, 2010; Trilling et al.,2010; Holden et al.,2015; AL Owad et al.,2014; MANDAHAWI et al.,2011; BHAT et al.,2015;. proudlove et al.,2008).

According to literature evidence, VSM has also been associated with simulation technique as shown in papers such as Dogan Nutulmaz (2014), Bhat et al., (2015),
Robinson et al., (2012). Doğan et Nutulmaz (2014) used the VSM and simulation techniques to improve the efficiency of healthcare. The authors used the VSM to map the current and future states of patient flow and then each map was modeled through simulation. Robinson et al., (2012) argue that the most common use for discrete event simulation was in the form of an electronic VSM and the benefits of such have been described as a display "dynamic" process that can be used interactively with the additional benefit of being able to demonstrate the value stream mapping (VSM).

Kaizen has also been widely adopted by the authors surveyed in this review. The Kaizen itself is not a tool but a philosophy or practice that seeks continuous improvement processes in order to eliminate waste. However, in several articles have been cited the terms "kaizen Event ", "Rapid Improvement Event (RIE)" or "Kaizen Blitz" (NICHOLAS, 2012; RADNOR et al., 2012; Mazzocato et al., 2011; CREMA et al., 2015; MAZUR et al., 2012; LAGANGA, 2011; NAIK et al., 2011; Taylor et al., 2014; ZANIN et al., 2011;. Venkateswara et al., 2011; JACKSON et MAZUR, 2011). According to Nicholas (2012), "Kaizen event" is a procedure lasting 3 to 5 days in which the team learns the Lean method, investigates the process, and identifies the issues and causes and implementing improvements. In this aspect, "Kaizen event", RIA or "Kaizen Blitz" can be considered as a Lean tool and the evidence found in the literature review shows that it is widely used in the Lean Healthcare implementation process

Another Lean tool among the most cited was the 5S. This tool, although very simple, was useful to achieve the goals of Lean Healthcare. Esain et al., (2008) found in their study that implementing $5 \mathrm{~S}$ tool is useful for understanding the processes and sets out the steps to change.

This literature review has shown how diverse is the use and implementation of Lean Healthcare tools and techniques. The exploited literature showed the occurrence of studies, which have used one or two tools only, but also, showed other studies adopting a much larger number. A question that arises is whether the mere fact of using a Lean tool transforms a health organization in a lean one. Grove et al., (2010) mention that the recent focus on efficiency gains have led to a series of partial implementations of Lean, as with health managers who have tried to replicate the success of others without understanding the fundamental principles of Lean. Therefore, critical determinants must be put in place before embarking on a Lean transformation. These determinants have been adapted by the authors Grove et al., (2008) to an iceberg model shown in Figure 9.

In this iceberg implementation model of Lean tools and techniques Lean are the top of the iceberg and are easily identified and are often used for a quick fix, but an implementation of closer Lean requires all tasks from the bottom to the top (Grove et al.,2008). 


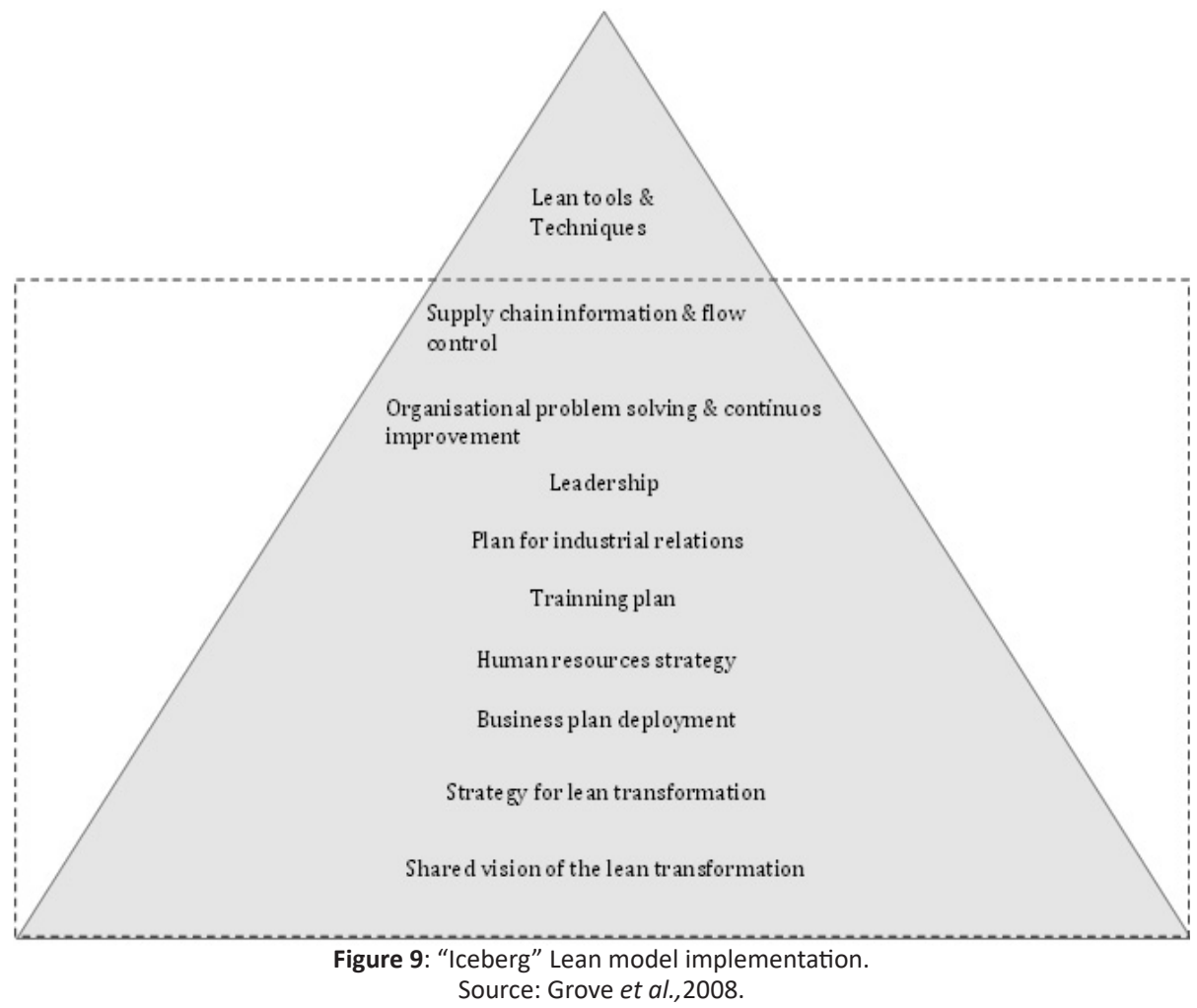

About "Leagile" concept, when we search SCOPUS data base for the string "Leagile", only 71 papers come up and when we narrow the search using the string "Healthcare" within "Leagile" results, only 5 documents came up. Reading the 5 articles, we realized that only 3 really bring Healthcare cases of study. This means that studies concerning these subjects are still in its infant stages and needs further studies.

\section{CONCLUSION}

As the main conclusion, we can highlight the still short number of papers studying Lean, Agile and Leagile practices and tools applied to healthcare organizations. Most of these organizations, which have tried to implement some of the tools, still do not fully understand the challenges and effort needed for Lean practices. We also hope this review can help new researchers, being a primary guide of what is already being published concerning the subject.

\section{ACKNOWLEDGMENTS}

This is part of a scientific initiation program of CEFET/RJ. The authors of this article would like to thank the CEFET/RJ for the financial support offered through scientific initiation scholarship.

\section{REFERENCES}

AGARWAL, A.; SHANKAR, R.; TIWARI, M.K. Modeling the metrics of lean, agile and leagile supply chain : An ANPbased approach. , 173, pp.211-225, 2006.
AGUEZZOUL, A.; NYOUNGUE, A. A preliminary analysis on Lean Six Sigma application in healthcare. IEEE, 2012.

AGUILAR-ESCOBAR, V. G.; GARRIDO-VEGA, P. Gestión Lean en logística de hospitales: estudio de un caso. Revista de Calidad Asistencial. v. 28, n.1, p. 42-49, 2013.

AHMED, S.; MANAF, N. H.; ISLAM, R. Effects of Lean Six Sigma application in healthcare services: a literature review. Reviews on Environmental Health, vol. 28, n. 4, p. 189-194, 2013.

AL OWAD, A.; KARIM, M. A.; MA, L. Integrated Lean Six Sigma Approach for Patient Flow Improvement in Hospital Emergency Department. Advanced Materials Research, vols. 834-836, p. 1893-1902, 2014.

BAHENSKY, J. A.; ROE, J.; BOLTON, R. Lean sigma-will it work for healthcare? Journal of healthcare information management : JHIM, vol. 19, n. 1, p. 39-44, 2005.

BALAJI, M.; VELMURUGAN, V.; SIVABALAN, G.; ILAYARAJA, V. S.; PRAPA, M.; MYTHILY, V. ASCTM Approach for Enterprise Agility. Procedia Engineering. pp.2222-2231. 2014. Disponível em: <http://linkinghub.elsevier.com/retrieve/pii/ S187770581403536X>.

BARIL, C.; GASCON, V.; MILLER, J.; C^OT', N. Use of a discrete-event simulation model during a Lean process: a case study in healthcare European Journal of Operational Research volume 249 pp 327-339 n.1

BASTIAN ,N. D.; MUNOZ, D.; VENTURA, M. A MixedMethods Research Framework for Healthcare Process 
Improvement1 Journal of Pediatric Nursing, 31, e39-e51A, 2016.

BHAT, S.; GIJO, E.V.; JNANESH, N.A. Application of Lean Six Sigma methodology in the registration process of a hospital. International Journal of Productivity and Performance Management, vol. 63, n. 5, p. 613-643, 2015.

BIRHANU, D.; LANKA, K.; RAO, N. A Survey of Classifications in Supply Chain Strategies. Procedia Engineering. 97, pp.2289-2297. 2014. Disponível em: <http://dx.doi. org/10.1016/j.proeng.2014.12.473>.

BONILLA, C.; PAWLICKI, T.; PERRY, L.; WESSELINK, B. Radiation oncology Lean Six Sigma project selection based on patient and staff input into a modified quality function deployment. International Journal of Six Sigma and Competitive Advantage, vol. 4, n. 3, p. 196, 2008.

CABRAL, I.; GRILO, A.; CRUZ-MACHADO, V. Decisionmaking model for lean, agile, resilient and green supply chain management. International Journal of Production Research. Volume 50, Issue 17, 2012.

CALDWELL, C. Lean-Six Sigma: tools for rapid cycle cost reduction. Healthcare financial management: Journal of the Healthcare Financial Management Association, vol. 60, n. 10, p. 96-98, 2006.

CARBONEAU, C.; BENGE, E.; JACO, M. T.; ROBINSON, M. A lean Six Sigma team increases hand hygiene compliance and reduces hospital-acquired MRSA infections by $51 \%$. Journal for healthcare quality : official publication of the National Association for Healthcare Quality, vol. 32, n. 4, p. 61-70, 2010.

CHEN, J.; CHENG, C.-H.; HUANG, P. B.; WANG, K.-J.; HUANG; C.-J.; TING, T.-C. Warehouse management with lean and RFID application: A case study. International Journal of Advanced Manufacturing Technology. v. 69, n (1-4), p.531542. 2014. Disponível em: <http://dx.doi.org/10.1016/j. eswa.2012.12.047>.

CHENG, S. Y.; BAMFORD, D. R.; PAPALEXI, M.; DEHE, B. Improving access to health services - challenges in Lean application. International Journal of Public Sector Management. v. 28, p. 121-135, 2015.

CHIOCCA, D. A; GUIZZI, G. A.; MURINO, T. A.; REVETRIA, R. B.; ROMANO, E. A. A methodology for supporting lean healthcare Studies in Computational Intelligence Volume 431, Pages 93-99. 2012.

CHRISTOPHER, M.; TOWILL, D. R. Developing market specific supply chain strategies. International Journal of Logistics Management 13(1), 2002.

CHRISTOPHER, M.; PECK, H.; TOWILL, D. A taxonomy for selecting global supply chain strategies. International Journal of Logistics Management. v. 17, n. 2, p. 277-287. 2006.
CHRISTOPHER, M. The agile supply chain. Ind. Market. Manage. v. 29, n. 1, p. 37-44. 2000.

COOPER, M.; LAMBERT, D.; PAGH, J. Supply Chain Management: More than a new name for Logistics. International Journal of Logistics Management. v. 8, n. 1, p. 1-14. 1997.

CREMA, M.; VERBANO, C. How to combine lean and safety management in health care processes: A case from Spain. Safety Science, vol. 79, p. 63-71, 2015.

CREMA, M.; VERBANO, C.; CHIOZZA, M. L. First evidences from "lean \& safety" projects. International Journal of Quality and Service Sciences, vol. 7, n. 2/3, p. 245-259, 2015.

CROXTON, K.; DASTUGUE, S.; LAMBERT, D.; ROGERS, D. The Supply Chain Management Processes. The International Journal of Logistics Management. v. 12, n. 2, p.13-16. 2001.

CURATOLO, N. A.; LAMOURI, S. A.; HUET, J.-C. B.; RIEUTORD, A. C. A critical analysis of Lean approach structuring in hospitals. Business Process Management Journal ,Volume 20, Issue 3, Pages 433-454, 2014.

D’ANDREAMATTEO, A.; IANNI, L.; LEGA, F.; SARGIACOMO, $M$. Lean in Healthcare: a comprehensive review. Health Policy, vol. 119, n. 9, p. 1197-1209, 2015.

DEMIRLI, K.; BHUIYAN, N. A general framework for lean transformation of hospitals. 2015 International Conference on Industrial Engineering and Operations Management (IEOM), 2015.

DIAS, D. G.; MENDES, C.; DA SILVA, M. M. A Method for Reengineering Healthcare Using Enterprise Ontology and Lean Communications in Computer and Information Science. Volume 415, 2013, Pages 243-259 4th International Joint Conference on Knowledge Discovery, Knowledge Engineering and Knowledge Management, IC3K 2012; Barcelona; Spain, 2012.

DiGIOIA, A. M.; GREEHOUSE, P. K.; CHERMAK, T.; HAYDEN, M. A. A case for integrating the Patient and Family Centered Care Methodology and Practice in Lean healthcare organizations. Healthcare. 2015.

DOĞAN, N. Ö.; UNUTULMAZ, O. Lean production in healthcare: a simulation-based value stream mapping in the physical therapy and rehabilitation department of a public hospital. Total Quality Management \& Business Excellence, 2014.

DUNCAN, E.; RITTER, R. Next frontiers for lean. Mckinsey and Company. 2014. Disponível em: <http://www. mckinsey.com/insights/Manufacturing/Next_frontiers_for lean?cid=manufacturing-eml-alt-mkq-mck-oth-1402>.

ESAIN, A.; WILLIAMS, S.; MASSEY, L. Combining planned and emergent change in a healthcare lean transformation. Public Money and Management, vol. 28, n. 1, p. 21-26, 2008. 
FUND, C. "International profiles of healthcare systems, 2012," Commonwealth Fund Publication, pp. 113, 2011.

GIJO, E. V.; ANTONY, J. Reducing Patient Waiting Time in Outpatient Department Using Lean Six SigmaMethodology. Quality and Reliability Engineering International, vol. 30, p. 1481-1491, 2014.

GLIGOR, D.; ESMARK, C.; HOLCOMB, M. Performance outcomes of supply chain agility: When should you be agile? Journal of Operations Management. v. 33-34, p.7182. 2014 Disponível em: <http://dx.doi.org/10.1016/j. jom.2014.10.008>.

GLIGOR, D.; HOLCOMB, M. Understanding the role of logistics capabilities in achieving supply chain agility: a systematic literature review. Supply Chain Management: An International Journal. v. 17, n. 4, p.438-453. 2012a.

GOLDSBY, T.; GRIFFIS, S.; ROATH, A. Modeling lean, agile, and leagile supply chain strategies. Journal of Business Logistics. v. 27, n. 1, p.57-80. 2006.

GRABAN, M. Lean Hospitals - Improving Quality, Patient Safety, and Employee Engagement. 2nd ed. Boca Raton, FL: Taylor \& Francis Group. 2012.

GROVE, A. L.; MEREDITH, J. O.; MACINTYRE, M.; ANGELIS, J.; NEAILEY, K. UK health visiting: challenges faced during lean implementation. Leadership in Health Services, vol. 23, n. 3, p. 204-218, 2010.

HAENKE, R.; STICHLER, J. F. Applying Lean Six Sigma for innovative change to the post-anesthesia care unit. The Journal of nursing administration, vol. 45, n. 4, p. 185-187, 2015.

HAMMER, M. A Agenda: O que as empresas devem fazer para dominar esta década. 3ạ ed. Rio de Janeiro: Campus. 2001.

HENRIQUE, D. B.; RENTES, A. F.; GODINHO FILHO, M.; ESPOSTO, K. F. A new value stream mapping approach for healthcare environments. Production Planning \& Control, vol. 27, n. 1, p. 24-48, 2005.

HEUVEL, J. V. D.; DOES, R. J.M.M.; KONING, H. D. Lean Six Sigma in a hospital. International Journal of Six Sigma and Competitive Advantage, vol. 2, n.4, p. 337, 2006.

HOERL, R. W.; GARDNER, M. M. Lean Six Sigma, creativity, and innovation. International Journal of Lean Six Sigma, vol. 1, n. 1, p. 30-38, 2010.

HOLDEN, R. J.; ERIKSSON, A.; ANDREASSON, J.; WILLIAMSSON, A.; DELLVE, L. Healthcare workers' perceptions of lean: a context-sensitive, mixed methods study in three Swedish hospitals. Applied ergonomics, vol. 47, p. 181-192, 2015.

HOUCHENS N.; KIM S. C. The Application of Lean in the Healthcare Sector: Theory and Practical Examples, in
Wickramasinghe et al., Lean thinking for Healthcare sector, pp.43-53, Springer New York. 2014.

HUANG, Y.; LI, X.; WILCK, J.; BERG, T. Cost reduction in healthcare via Lean Six Sigma. 62nd IIE Annual Conference and Expo 2012, p. 1263-1270, 2012.

HUANG, Y.-Y.; LI, S.-J. How to achieve leagility: A case study of a personal computer original equipment manufacturer in Taiwan. Journal of Manufacturing Systems. v. 29, n. (2-3), p.63-70. 2010. Disponível em: <http://dx.doi.org/10.1016/j. jmsy.2010.09.001>.

JACKSON, M.; MAZUR, L. M. Exploring lean healthcare transformation using the theory of planned behavior. 61st Annual IIE Conference and Expo Proceedings, 2011.

JIMMERSON, C.; WEBER, D.; SOBEK, D. K. Reducing waste and errors: piloting lean principles at Intermountain Healthcare. Joint Commission Journal on Quality and Patient Safe, vol. 31, n. 4, p. 249-257, 2005.

JÜTTNER, U.; PECK, H.; CHRISTOPHER, M. Supply chain risk management: outlining an agenda for future research. International Journal of Logistics, v. 6, n. 4, p. 197-210. 2003.

KOLLENGODE, A. Power of observation for lean six sigma initiatives in health care. Society for Health Systems Conference and Expo. 2008.

KONING, H.; VERVER, J. P. S.; HEUVEL, J. V. D; BISGAARD, S.; DOES, R. J. M. M. Lean Six Sigma in Healthcare. Journal for Healthcare Quality, vol. 28, n. 2, p. 4-8, 2006.

KUBILIUS, A.; WINFREY, K.; MAYER, C.; JOHNSON, G.; WILSON, T. Applying Lean Six Sigma tools to reduce the rate of slips, trips and falls for Joint Commission field staff. International Journal of Six Sigma and Competitive Advantage, vol. 9, n. 1, p. 37, 2015.

KUO, A. M.; BORYCKI, E.; KUSHNIRUK, A. LEE, T. A healthcare Lean Six Sigma System for postanesthesia care unit workflow improvement. Quality management in health care, vol. 20, n. 1, p. 4-14, 2011.

LAGANGA, L. Lean service operations: Reflections and new directions for capacity expansion in outpatient clinics. Journal of Operations Management, vol. 29, n. 5, p. 422433, 2011.

LASORSA, I. A.; LIUZZI, G. B.; CALABRESE, R. A.; ACCARDO, A. A. An innovative method for standardizing lean management approach in hospitals IFMBE Proceedings Volume 48, 2015, Pages 67-70 16th Nordic-Baltic Conference on Biomedical Engineering and Medical Physics and Medicinteknikdagarna Joint Conferences, NBC 2014 and MTD 2014; Gothenburg; Sweden; 2014.

LEE, H. L. Aligning supply chain strategies with product uncertainties. California Management Review . v. 44, n. 3, p.105-119. 2002. 
LI, X.; CHUNG, C.; GOLDSBY, T.; HOLSAPPLE, C. A unified model of supply chain agility: the work-design perspective. International Journal of Logistics Management. v. 19, n. 3, p.408-435. 2008.

LIN, W. An effective lean supply inventory management model using VMI hub. IEEE International Conference on Industrial Engineering and Engineering Management. p.950-954. 2001.

LING, L.; FENG, Z. Partner selection of Agile Supply Chain based on MAX-MIN ant system. 2013 6th International Conference on Information Management, Innovation Management and Industrial Engineering. p. 531-534. Disponível em: <http://ieeexplore.ieee.org/lpdocs/epic03/ wrapper.htm?arnumber $=6702991>$.

MACHADO, V. H.; BARROSO, A. P.; MACHADO, V.-C. An Analytic Network Process Model to Support Decision Making in a Pharmaceutical Supply Chain. IEEE International Conference on Industrial Engineering and Engineering Management. p. 1612-1616. 2013.

MANDAHAWI, N.; ARAIDAH, O. A.; BORAN, A.; KHASAWNEH, M. Application of Lean Six Sigma tools to minimise length of stay for ophthalmology day case surgery, International Journal of Six Sigma and Competitive Advantage, vol. 6, n. 3, p. 155-176, 2011.

MANZOURI, M.; AB-RAHMAN, M. N.; ZAIN, C. R. C. M.; JAMSARI, E. A. Increasing Production and Eliminating Waste through Lean Tools and Techniques for Halal Food Companies. Sustainability, v. 6, n. 12, p.9179-9204. 2014. Disponível em: <http://www.mdpi.com/2071-1050/6/12/9179>.

MASON, S. E.; NICOLAY, C. R.; DARZI, A. The use of Lean and Six Sigma methodologies in surgery: A systematic review. The Surgeon, vol. 13, n. 2, p. 91-100, 2014.

MASON-JONES, R.; NAYLOR, B.; TOWILL, D. Engineering the leagile supply chain. International Journal of Agile Management Systems. v. 2, n. 1, p.54-61. 2000.

MAZUR, L.; McCREERY, J.; ROTHENBERG, L. Facilitating Lean Learning and Behaviors in Hospitals During the Early Stages of Lean Implementation. Engineering Management Journal, vol. 24, n. 1, p. 11-22, 2012.

MAZZOCATO, P.; CARL SAVAGE, MATS BROMMELS, Lean thinking in healthcare: a realist review of the literature et al. Qual Saf Health Care, 19: 376-382 originally published online August, 2010.

MAZZOCATO, P.; HOLDEN, R. J.; BROMMELS, M.; ARONSSON, H.; BÄCKMAN, U.; ELG, M.; THOR, J. How does lean work in emergency care? A case study of a lean-inspired intervention at the Astrid Lindgren Children's hospital, Stockholm, Sweden. BMC Health Services Research, vol. 12, n. 21, 2012.
McCLEAN, S.; GARG, L.; MEENAN, B.; MILLARD, P. Using Markov Models to find Interesting Patient Pathways. Proceedings - IEEE Symposium on Computer-Based Medical Systems. 2007.

McINTOSH, B.; SHEPPY, B.; COHEN, I. Illusion or delusion Lean management in the health sector, International Journal of Health Care Quality Assurance. v. 27, n. 6, p. 482 - 492, 2014.

MOZAMMEL, A.; MAPA, L. B.; SCACHITTI, S. Application of Lean Six Sigma in healthcare - A graduate level directed project experience. ASEE Annual Conference and Exposition, Conference Proceedings, 2011.

NAIK, T.; DUROSEAU, Y.; ZEHTABCHI, S.; RINNERT, S.; PAYNE, R.; MCKENZIE, M.; LEGOME, E. A structured approach to transforming a large public hospital emergency department via lean methodologies. Journal for Healthcare Quality, vol. 34, n. 2, p. 86-97, 2011.

NATALE, J.; WANG, S.; TAYLOR, J. Using lean six sigma to transform hospital system primary care practices into a patient-centered medical home. IIE Annual Conference and Expo 2014, p. 213-222, 2014.

NAYLOR, B.; NAIM, M.; BERRY, D. Leagility: interfacing the lean and agile manufacturing paradigm in the total supply chain. International. Journal of Production Economics. v. 62, n.1, p.107-118. 1999.

NICHOLAS, J. An Integrated Lean-Methods Approach to Hospital Facilities Redesign. Hospital Topics, vol. 90, n. 2, p. 47-55, 2012.

NICOLAY, C. R.; PURKAYASTHA, S.; GREENHALGH, A.; BENN, J.; CHATURVEDI, S.; PHILLIPS, N.; DARZI, A. Systematic review of the application of quality improvement methodologies from the manufacturing industry to surgical healthcare. British Journal of Surgery, vol. 99, n. 3, p. 324-335, 2012.

PHIPPS, R. Successful lean-six sigma in healthcare a case study division of pathology \& laboratory medicine. 62nd IIE Annual Conference and Expo 2012, 2012.

POKSINSKA, B. The current state of Lean implementation in health care: literature review, Quality Management in Health Care, Vol.19, No.4, pp.319-329. 2010.

PRINCE, J.; KAY, J. Combining lean and agile characteristics: creation of virtual groups by enhanced production flow analysis. International Journal of Production Economics. v. 85, n.3, p.305-318. 2003.

PROUDLOVE, N.; MOXHAM, C.; BOADEN, R. Lessons for lean in healthcare from using six sigma in the NHS. Public Money and Management, vol. 28, n. 1, p. 27-34, 2008.

RADNOR, Z. J.; HOLWEG, M.; WARING, J. Lean in healthcare: The unfilled promise? Social Science and Medicine, vol. 74, n. 3, p. 364-371, 2012. 
ROBINSON, S.; RADNOR, Z. J.; BURGESS, N.; WORTHINGTON, C. SimLean: Utilising simulation in the implementation of lean in healthcare. European Journal of Operational Research, vol. 219, n. 1, p. 188-197, 2012.

SAFAEI, M. An integrated multi-objective model for allocating the limited sources in a multiple multi-stage lean supply chain. Economic Modelling. v.37, p.224237. 2013. Disponível em: http://dx.doi.org/10.1016/j. econmod.2013.10.018.

SANDERS, J. H.; KARR, T. improving ed specimen tat using Lean Six Sigma. International journal of health care quality assurance, vol. 28, n. 5, p. 428-440, 2015.

SANGARI, M. S.; RAZMI, J.; ZOLFAGHARI, S. Developing a practical evaluation framework for identifying critical factors to achieve supply chain agility. Measurement. v. 62, p.205214. 2014. Disponível em: <http://dx.doi.org/10.1016/j. measurement.2014.11.002>.

SEURING, S.; GOLD, S. Conducting content-analysis based literature reviews in supply chain management. Supply Chain Management: An International Journal, vol. 17, n. 5 p. $544-555,2012$.

STURDEVANT, D. (Still) learning from Toyota. Mckinsey and Company. 2014. Disponível em: <http://www.mckinsey. com/insights/Manufacturing/Still_learning_from_ Toyota?cid=manufacturing-eml-alt-mkq-mck-oth-1402>.

SUKATI, I.; HAMID, A B.; BAHARUN, R.; YUSOFF; R. M. The Study of Supply Chain Management Strategy and Practices on Supply Chain Performance. Procedia - Social and Behavioral Sciences. v. 40, p.225-233. 2012. Disponível em: <http://dx.doi.org/10.1016/j.sbspro.2012.03.185>.

SUKWADI, R., WEE, H., YANG, C. Supply Chain Performance Based on the Lean-Agile Operations and Supplier-Firm Partnership: An Empirical Study on the Garment Industry in Indonesia. Journal of Small Business Management. v. 51, n. 2, p.297-311, 2013.

SWAFFORD, P.; GHOSH, S.; MURTHY, N. The antecedents of supply chain agility of a firm: scale development and model testing. Journal Operation Management. v.24, n.2, p.170-188. 2006.

TANG, O.; LI, J.; MUSA, S. B. Dynamic pricing policy in a Newsboy problem with supply yield risk. International Journal of Production Economics. 2011.

TAYLOR, K.; MAZUR, L.; CHERA, B.; ADAMS, R.; MOSALY, P.; JACKSON, M.; MARKS, L. Application of "A3 thinking" to operational improvements in radiation oncology. IIE Annual Conference and Expo, 2014.

THUN, J.-H.; HOENIG, D. An Empirical Analysis of Supply Chain Risk Management in the German Automotive Industry. International Journal of Production Economics. v. 131, n. 1, p. 242-249. 2011.
YU, T.; DEMIRLI, K.; BHUIYAN, N. A general framework for lean transformation of hospitals. Industrial Engineering and Operations Management (IEOM), International Conference on Dubai, pp. 1-8. , 2015.

TOWILL, D. R.; CHRISTOPHER, M. An evolutionary approach to the architecture of effective healthcare delivery systems. Journal of health organization and management, vol. 19, n. 2, p. 130-147, 2005.

TRILLING, L.; PELLET, B.; DELACROIX, S.; COLELLA-FLEURY, H.; MARCON, E. Improving care efficiency in a radiotherapy center using Lean philosophy: A case study of the Proton Therapy Center of Institut Curie - Orsay. 2010 IEEE Workshop on Health Care Management, 2010.

TRITOS, L., PREMARATNE, S., DOTUN, A., International Conference on Industrial Engineering and Engineering Management. Prioritizing Lean Supply Chain Management Initiatives in Healthcare Service Operations: A Fuzzy-AHP Approach. pp. 236-242. 2013.

VENKATESWARAN, V.; IKUMA, L.; NAHMENS, I.; PIRCH, E. Using Kaizen to improve acute rehabilitation processes. 61st Annual IIE Conference and Expo Proceedings, 2011.

VEST, J. R.; GAMM, L. D. A critical review of the research literature on Six Sigma, Lean and Studer Group's Hardwiring Excellence in the United States: the need to demonstrate and communicate the effectiveness of transformation strategies in healthcare. Implementation science : IS, vol. 4, n. 5, 2009.

VILLA, D. Automation, Lean, Six Sigma: Synergies for improving laboratory efficiancy. Journal of Biomedic Biochemistry, vol. 29, n. 4, p. 339-348, 2010.

VILLARREAL, M. C.; YILMAZ, T. A Pediatric intensive care unit rounding process lean transformation. IIE Annual Conference and Expo 2010 Proceedings 2010; Cancun; Mexico; 5 June 2010 through 9 June 2010.

VORST, J.; DIJK, S.; BEULENS A. Leagile supply chain design in food industry: an inflexible poultry supply chain with high demand uncertainty. The International Journal on Logistics Management. v. 12, n. 2, p. 73-85. 2001.

WORKMAN-GERMANN, J.; WOODWARD-HAGG, $\mathrm{H}$. Implementing lean six sigma methodologies in the radiology department of a hospital healthcare system. ASEE Annual Conference and Exposition, Conference Proceedings, 2006.

YAMAMOTO, J.; ABRAHAM, D.; MALATESTINIC, B. Improving Insulin Distribution and Administration Safety Using Lean Six Sigma Methodologies. Hosp Pharm, vol. 45, n. 3, p. 212-224, 2010.

YU, Q.; YANG, K. Hospital registration waiting time reduction through process redesign. International Journal of Six Sigma and Competitive Advantage, vol. 4, n. 3, p. 1-24, 2008. 
YUSUF, Y. Y.; GUNASEKARAN, A.; MUSA, A.; DAUDA, M.; N.; EL-BERISHY, M.; CANG, S. A relational study of supply chain agility, competitiveness and business performance in the oil and gas industry. International Journal of Production Economics. v. 147(PART B), p.531-543. 2012. Disponível em: <http://dx.doi.org/10.1016/j.ijpe.2012.10.009>.

ZANDI, F.; BORCHERS, A. S. A roadmap to evaluate lean six sigma e-health reference architectures using a fuzzy group Bi-Objective LINMAP. 18th Americas Conference on Information Systems 2012, AMCIS 2012, vol. 3, p. 24092429, 2012.

ZANIN, M.; WANG, S.; HILLMAN, M. Implementing a Kaizen in an aged and over-utilized hospital emergency department. 61st Annual IIE Conference and Expo Proceedings, 2011. 